\title{
Ssiendo
}

DOI 10.2478/afepuc-2020-0002

(C) Acta Facultatis Educationis Physicae Universitatis Comenianae 2020, 60(1): 15-31

\section{THE EFFECT OF MOVEMENT INTERVENTION ON MUSCULOSKELETAL SYSTEM IN UNDERGRADUATES}

\author{
Rút Lenková ${ }^{1}$, Iveta Boržíková ${ }^{1}$, Wioletta Mikul'áková ${ }^{2}$, \\ Monika Vašková ${ }^{1}$, Veronika Vasilišinová ${ }^{1}$ \\ ${ }^{1}$ Faculty of Sport Prešov University in Prešov, Slovakia \\ ${ }^{2}$ Faculty of Health Care Prešov University in Prešov, Slovakia
}

\begin{abstract}
Summary: The aim of the research was to diagnose manifestations of functional and structural disorders and consider the effect of intervention on the musculoskeletal system of students of teacher's program of physical education. A total of 40 students of Faculty of Sports Prešov University in Prešov participated in the research. As part of the experiment we designed a targeted movement program as an intervention and applied it to an experimental group of students. After 5 months of the intervention, the measurements were repeated. In experimental group we noticed that $30 \%$ of men and $20 \%$ of women improved from III. to II. qualitative degree of shortened muscles. The statistically significant difference $(\mathrm{p}<.05)$ was confirmed in group of men. From the perspective of intersexual differences, we observed a statistically significant difference among the shortened muscles in the experimental group $(\mathrm{p} \leq .05)$. Changes in structural disorders of the spine after the intervention were statistically insignificant. In regards to good spinal health and muscle balance, we assume that targeted movement program can have preventive effect against functional and structural disorders.
\end{abstract}

Key words: hypokinesis, spine mobility, shortened muscles, fascial training program.

\section{Introduction}

Knowledge of the current lifestyle of the population shows a decreasing interest in regular physical activity in all age categories and the associated appearance of civilization diseases. Approximately one in two students at Slovak universities do not spend their free time regularly doing physical activity, resp. do sports only occasionally. Students report workload and stress factors as the most common reason for hypokinesis but are unaware of the need for recovery, which is only achieved by compensating lack of exercise (Véle 2006). 
These negative factors are also reflected in the musculoskeletal system of the current young generation. Static-dynamic function of the musculoskeletal system is disrupted leading to clinical syndromes and generally reducing the tolerance threshold for physical load (Dostálová \& Sigmund 2017).

Functional disorders of the musculoskeletal system refer to all disorders of joint, muscle, nerve and organ function where the primary cause of the disharmony is not a structural cause. Malfunction is a manifestation of a malfunctioning control function, whether it's a limitation of joint mobility, increased resp. decreased muscle tension or impaired movement stereotype (Véle 2006; Beránková, Grmela, Kopřivová \& Sebera 2012). There are three main levels of the musculoskeletal system where function disorders occur: central nervous movements regulation, muscle and joints (Lenková \& Boržíková 2018). These levels can not be separated from each other, they're interrelated and they interact. However, scientific knowledge of recent years shows that muscle factor plays a crucial role in most functional disorders of the musculoskeletal system (Bendíková 2010; Kanásová 2017). Important is the functional relationship between the muscles, speaking of muscle balance (Dostálová \& Sigmund 2017), which arises from a violation of functional relationships between the postural and phasic muscular system. It is often the result of insufficient, excessive but also one-sided movement overload (Bendíková 2016; Lenková, Mikuláková, Labunová \& Urbanová 2018).

Postural muscles perform a predominantly static function, keeping the body upright. Their primary functional feature is that they have a strong tendency for shortening that occurs throughout life as an adaptive response to inappropriate functional loads (Norris 1995; Čermák, Chválová, Botlíková \& Dvořáková 2008; Bursová 2005; Dostálová \& Sigmund 2017). According to Kolář et al. (2009) muscle shortening is a condition where, for a various reasons, resting shortening occurs. The shortened muscle loses the ability to fully relax and reach its original length. By passive stretching, the full range of motion can not be achieved. Muscles with tendency to shorten tend to be hyperactive, so compared to other muscle groups they are more often activated in situations where they should not be activated and take over the function of phasic muscles.

Muscle imbalance negatively affects body posture, movement stereotypes, muscle coordination, increases the risk of injury and, in addition, limits joint movement and mobility (Kopřivová \& Beránková 2002; Bendíková 2016). If the muscles can not resist the overload, 
the ligaments and joints take responsibility for the shape of the spine, very often leading to degenerative changes that are accompanied by pain (Dylevský 2009; Górnicka 2014).

The physiological curvature of the spine within the sagittal plane is shaped in the process of posturogenesis and is characterized by high plasticity and the level of curvature of the spine in the sagittal plane depends on many factors such as somatotype, lifestyle of physical activity. Excessive overloading of the spine in the form of a long-term sitting position, inactivity without compensation or asymmetric stress can lead to pathological curvature of the spine and decreased quality of life (Lichota \& Plandowska 2011; Mikuláková, Urbanová, Lenková \& Boržíková 2017; American Heart Association 2015).

Within the sagittal plane we mention cervical and lumbar lordosis, thoracic and sacral kyphosis. Lordic-kyphotic curvature of the spine helps to absorb and ease shock impacts. Due to various factors, there are significant curvature of the given spinal segments, which is perceived as a manifestation of deformity. The upper sacral syndrome typically has a accompanying phenomenom in the form of thoracic hyperkyphosis, while the lower sacral syndrome manifests itself as hyperlordosis in the lumbar segment. The reduced curvature of the spine in terms of hypokyphosis and hypolordosis in all its segments is known as the „flat back" which is also considered to be the non-optimal condition of the spine. Within the deviation of the curvature of the spine in the frontal plane, we are talking about scoliosis, resp. scoliotic curvature of the spine. Progressive decline of spinal mobility is generally accepted as one of the main causes of spinal deformity (Aebi 2005).

The aim of our research was to diagnose structural abnormalities and functional disorders of the musculoskeletal system of students of teacher's program of physical education and to intentionally correct them by means of an interventional movement program. Regard to the sedentary lifestyle of university students, who analyze researches Šimončičová \& Kanásová (2014), Levitová \& Hošková (2015), Chen, Yarnal, Hustad \& Sims (2016), we anticipated changes in the curvature and mobility of the spine and $75 \%$ incidence of functional disorders in shortened muscle dimension. By the intervention of the targeted movement program, we expected changes in the level of musculoskeletal system disorders of the experimental group compared to the control group without intervention.

\section{Methods}

The object of our research was a group of 40 students from the 1st year of the bachelor's degree study program Physical Education Teaching at the Faculty of Sports of the 
University of Prešov in academic year 2018/2019. The experimental group (EG) consisted of 20 students (10 men and 10 women). The average age of the experimental group men was $20.2 \pm 0.65$ years. They had an average body height $179.5 \pm 6.15 \mathrm{~cm}$, an average body weight $75.96 \pm 8.23 \mathrm{~kg}$ and an average BMI 23.57 \pm 2.45 . The average age of EG women was $19.1 \pm$ 0.53 years, the average body height was $167.9 \pm 5.25 \mathrm{~cm}$, the average body weight was $57.4 \pm$ $6.85 \mathrm{~kg}$ and the BMI was $20.3 \pm 1.78$. The control group (CG) consisted of 20 students (11 men and 9 women). The average age of men and women was $19.55 \pm 0.68$ years. The average body height of men was $182.3 \pm 5.25 \mathrm{~cm}$ and body weight was $73.2 \pm 8.42 \mathrm{~kg}$. The average body height of CG women was $164.98 \pm 4.85 \mathrm{~cm}$, body weight on average $60.6 \pm 3.65 \mathrm{~kg}$. Given the average body height and weight, the BMI index for men was $22.1 \pm 1.93$ and for women was $22.8 \pm 2.24$.

Muscles that tend to shorten were diagnosed by 11 testS according to Janda (1982), modified by Thurzová (1992) for physical educational practise. Diagnoses of curvature and mobility of the spine was performed by using SpinalMouse ${ }^{\circledR}$ diagnostic technology, which records spinal movements during tests in the sagittal and frontal planes. Spinal mobility tests were performed from baseline and the extent of movement in torso flexion and extension within the sagittal plane, lateroflexions within the frontal plane as well as from baseline was measured. The data obtained during the diagnostics were recorded by the SpinalMouse ${ }^{\circledR}$ software, which graphically presented the curvature of the spine in individual sections. The software visualized problem spine areas as well as any deviations from the reference values (Mikuláková, Urbanová, Lenková \& Boržíková 2017). The results show an excellent match when compared to X-ray documentation (Ripani et al. 2008; Dohi 2013).

The research was conducted as a parallel experiment. The experimental factor in the project was an interventional movement program, which was aimed at reducing muscle tension, stimulating and improving the flexibility of the fascia, increasing the mobility of individual spine sectors using blackrollers and various balancing instruments. Intervention lasted 5 months, EG students exercised 2 times a week for 45 minutes. In the course of the research investigation, both EG and CG ensembles were engaged in physical activities within the study program of physical education teachers - swimming, sports games, athletics, gymnastics in the extent of 5 hours per week. At the end of the experiment we performed a retest of the studied indicators.

The changes in the observed musculoskeletal system parameters of the students were calculated by chi-square $\chi^{2}$ at the significance level of $5 \%$. Using the same method we 
compared quantitative indicators. We used Mann-Whitney U Test for independent data to compare $\mathrm{EG}$ and $\mathrm{CG}$ and to determine intersexual differences in individual files. We compared the input and output measurements of the experimental set with Wilcoxon's paired test by percentage analysis. We considered the changes that occurred between the input and output measurements at the $5 \%$ significance level $(\mathrm{p} \leq .05)$.

\section{Results}

Functional disorders of the musculoskeletal system can be caused by incorrect movement habits or lack of movement. They are manifested by hypertonus of hypotonus in muscles, disturbance of static position of the spine, muscle imbalance, overload of muscles and ligaments at work and sports, pain in muscle and joints, joint blockage and impaired movement stereotypes (Levitová \& Hošková 2015). If the muscles can not resist the overload, the ligaments and joints take responsibility for the shape of the spine leading to degenerative changes that are accompanied by pain.

\section{Curvature and mobility of the spine}

SpinalMouse ${ }^{\circledR}$ spine curvature and mobility measurements within sagittal plane of future teachers of physical education and sports education are graphically designed in baseline, flexion and extension (Figure 1).
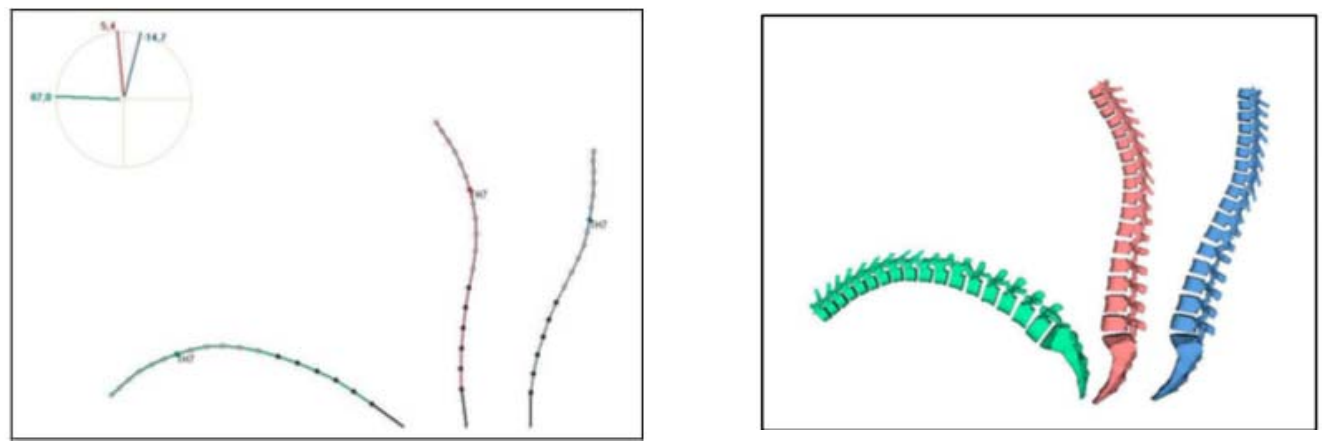

Figure 1

Visualisation of measurements within the sagittal plane (Source: SpinalMouse ${ }^{\circledR}$ software)

After diagnosing the backbone mobility of the students with the SpinalMouse ${ }^{\circledR}$ at baseline we found significant intersexual differences in the individual spine segments. In the thoracic segment, $67 \%$ of men had decreased curvature, $50 \%$ of women had increased curvature. In the lumbar segment were no significant differences in the shape of the spine between the sexes. In the sacral segment there was evident $50 \%$ hyperlordotic curvature of 
the spine in men $28.5 \%$ of tested women had increased curvature. Correct curvature was diagnosed in $50 \%$ of men and $71.5 \%$ of women (Table 1 ).

Table 1

The curvature of the spine in baseline within the sagittal plane

\begin{tabular}{|c|c|c|c|c|}
\hline \multicolumn{5}{|c|}{ The curvature of the spine in baseline within the sagittal plane } \\
\hline $\begin{array}{c}\text { Segments of the } \\
\text { spine }\end{array}$ & Sex & $\begin{array}{c}\text { Decreased } \\
\text { curvature (\%) }\end{array}$ & $\begin{array}{c}\text { Correct } \\
\text { curvature (\%) }\end{array}$ & $\begin{array}{c}\text { Increased } \\
\text { curvature ( \%) }\end{array}$ \\
\hline \multirow{2}{*}{ Thoracic } & M & 67.0 & 33.0 & 0 \\
\cline { 2 - 5 } & W & 0 & 50.0 & 50.0 \\
\hline \multirow{2}{*}{ Lumbar } & M & 50.0 & 33.0 & 17.0 \\
\cline { 2 - 5 } & W & 35.8 & 42.8 & 21.4 \\
\hline \multirow{2}{*}{ Sacral } & M & 0 & 50.0 & 50.0 \\
\cline { 2 - 5 } & W & 28.5 & 71.5 & 0 \\
\hline
\end{tabular}

(Source: author)

In flexion in the sagittal plane a hyperkyphotic curvature of the spine was found in the thoracic sector of men up to $92 \%, 17 \%$ in the lumbar sector, indicating limited mobility of the spinal sacral sector, an obvious sign of the occurence of muscular imbalance - lower sacral syndrome. Similar results were detectable in the group of women, the hyperkyphotic curvature of the spine in the thoracic sector was in $50 \%$ of tested women, the hypokyphotic curvature in the lumbar sector was in $35.7 \%$ (Table 2).

Table 1

Mobility of the spine - flexion within sagittal plane

\begin{tabular}{|c|c|c|c|c|}
\hline \multicolumn{5}{|c|}{ Mobility of the spine - flexion within sagittal plane } \\
\hline $\begin{array}{c}\text { Sectors of the } \\
\text { spine }\end{array}$ & Sex & $\begin{array}{c}\text { Decreased } \\
\text { curvature (\%) }\end{array}$ & $\begin{array}{c}\text { Correct } \\
\text { curvature ( \%) }\end{array}$ & $\begin{array}{c}\text { Increased } \\
\text { curvature ( \%) }\end{array}$ \\
\hline \multirow{2}{*}{ Thoracic } & M & 0 & 8.0 & 92.0 \\
\cline { 2 - 5 } & $\mathrm{W}$ & 7.1 & 42.8 & 50.0 \\
\hline \multirow{2}{*}{ Lumbar } & $\mathrm{M}$ & 33.0 & 50.0 & 17.0 \\
\cline { 2 - 5 } & $\mathrm{W}$ & 35.7 & 64.2 & 0 \\
\hline \multirow{2}{*}{ Sacral } & $\mathrm{M}$ & 75.0 & 25.0 & 0 \\
\cline { 2 - 5 } & $\mathrm{W}$ & 50.0 & 50.0 & 0 \\
\hline
\end{tabular}

(Source: author)

The results of standing and flexion measurements within the sagittal plane were confirmed in the extension of the trunk. In the group of males, $65.3 \%$ of probands had reduced mobility in the thoracic sector, the trunk extension was performed mainly in the lumbar sector of the spine, where $53.8 \%$ of the men experienced increased curvature, $42.8 \%$ of women had hyperkyphotic curvature in the thoracic sector. Reduced curvature in the lumbar sector was measured in $35.7 \%$ of women, in $92.8 \%$ of women we observed a reduced spine curvature in the sacral spinal sector. In the extension of the trunk, women mostly engage the thoracic and lumbar spinal sectors (Table 3). 
Table 3

Mobility of the spine - extension within sagittal plane

\begin{tabular}{|c|c|c|c|c|}
\hline \multicolumn{5}{|c|}{ Mobility of the spine - extension within sagittal plane } \\
\hline $\begin{array}{c}\text { Sectors of the } \\
\text { spine }\end{array}$ & Sex & $\begin{array}{c}\text { Decreased } \\
\text { curvature (\%) }\end{array}$ & $\begin{array}{c}\text { Correct } \\
\text { curvature ( \%) }\end{array}$ & $\begin{array}{c}\text { Increased } \\
\text { curvature ( \%) }\end{array}$ \\
\hline \multirow{2}{*}{ Thoracic } & $\mathrm{M}$ & 65.3 & 34.7 & 0 \\
\cline { 2 - 5 } & $\mathrm{W}$ & 42.8 & 54.2 & 3.0 \\
\hline \multirow{2}{*}{ Lumbar } & $\mathrm{M}$ & 2.7 & 43.5 & 53.8 \\
\cline { 2 - 5 } & $\mathrm{W}$ & 35.7 & 54.5 & 9.8 \\
\hline \multirow{2}{*}{ Sacral } & $\mathrm{M}$ & 7.3 & 69.2 & 23.5 \\
\cline { 2 - 5 } & $\mathrm{W}$ & 92.8 & 7.2 & 0 \\
\hline
\end{tabular}

(Source: author)

The results of the examination of the quality of spinal curvature in the frontal plane at baseline and lateroflexions to the right and to the left in individual spinal sectors in the study group are presented in Figure 2.
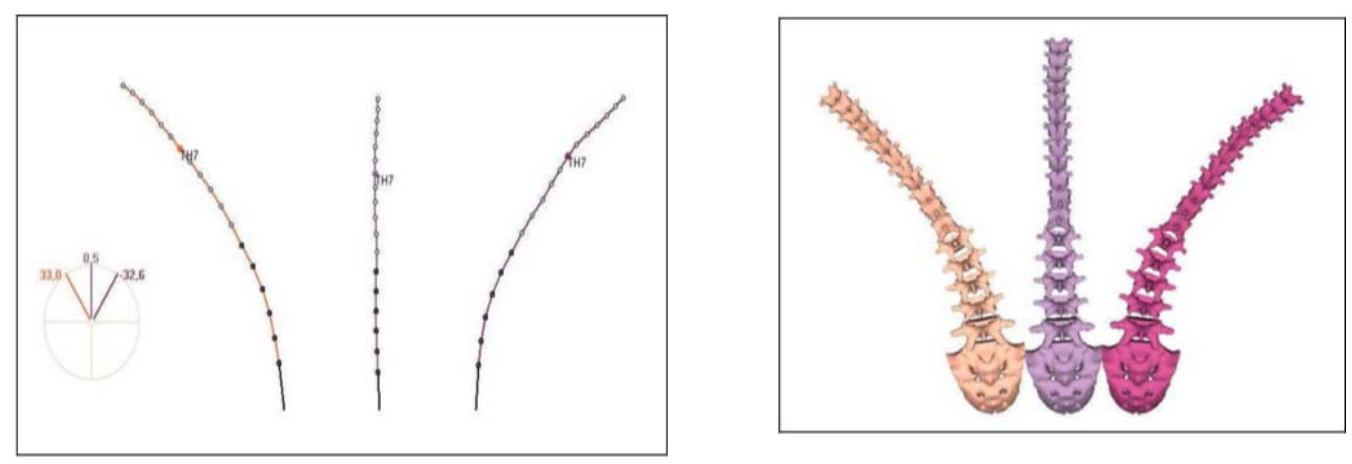

Figure 2

Visualisation of measurements in frontal (Source: SpinalMouse ${ }^{\circledR}$ software)

Within the frontal plane in the standing position, in lateroflexion on the right and left side, we found in the group of men the occurence of scoliotic curvature of the spine in all spinal sectors. The greatest deviation was noted in lateroflexion on the left in the sacral sector in up to $54.5 \%$ of probands and $38.2 \%$ in the lumbar sector. A similar finding was also found in lateroflexion on the right. In the group of women in the standing position we found that in the thoracic and sacral sector of the spine, all probands have the correct curvature. The most pronounced scoliotic curvature in lateroflexion in both directions was observed in the spinal sacral sector (Table 4).

Table 4

Curvature and mobility of the spine - lateroflexion within frontal plane

\begin{tabular}{|c|c|c|c|c|}
\hline \multicolumn{5}{|c|}{ Occurance of the scoliotic curvature } \\
\hline $\begin{array}{c}\text { Sectors of the } \\
\text { spine }\end{array}$ & Sex & $\begin{array}{c}\text { Baseline position } \\
(\mathbf{\%})\end{array}$ & $\begin{array}{c}\text { Lateroflexion to } \\
\text { the left (\%) }\end{array}$ & $\begin{array}{c}\text { Lateroflexion to } \\
\text { the right (\%) }\end{array}$ \\
\hline \multirow{2}{*}{ Thoracic } & $\mathrm{M}$ & 2.3 & 19.4 & 21.4 \\
\cline { 2 - 5 } & $\mathrm{W}$ & 0 & 15.1 & 15.2 \\
\hline \multirow{2}{*}{ Lumbar } & $\mathrm{M}$ & 12.4 & 38.2 & 32.5 \\
\cline { 2 - 5 } & $\mathrm{W}$ & 8.3 & 29.4 & 21.8 \\
\hline \multirow{2}{*}{ Sacral } & $\mathrm{M}$ & 3.4 & 54.5 & 52.7 \\
\cline { 2 - 5 } & $\mathrm{W}$ & 0 & 49.8 & 50.0 \\
\hline
\end{tabular}


Individual postural parameters represent similar values in input and output diagnostics. There were no statistically significant differences in the assessment of spinal mobility in individual sectors after the intervention. The result may be associated with similar characteristics of somatic properties in the study group. We note that a longer interval of targeted action of the experimental indicator is needed to achieve positive changes, given that the initial level of spinal mobility was insufficient by physiological recommendations (Kociová \& Mikuláková 2011). The limited mobility of the spine in the sagittal and frontal planes clearly points to significantly shortened postural muscles of EG students (Table 5).

Table 5

Average values $( \pm S D)$ of postural parameters in the sagittal and frontal planes of ES, statistical significance evaluated by t-test

\begin{tabular}{|l|c|c|c|c|}
\hline Postural parameters & Input $\left.\mathbf{(}^{\circ}\right)$ & Output $\left.\mathbf{(}^{\circ}\right)$ & T & p \\
\hline SR U sacral sector & $2.83 \pm 5.67$ & $1.30 \pm 7.13$ & .589 & .562 \\
\hline SR U thoracic sector & $35.58 \pm 11.85$ & $34.38 \pm 14.68$ & .223 & .825 \\
\hline SR U lumbar sector & $-16.75 \pm 7.20$ & $-14.53 \pm 9.67$ & -.644 & .526 \\
\hline SR F sacral sector & $71.00 \pm 15.66$ & $61.00 \pm 12.74$ & 1.757 & .092 \\
\hline SR F thoracic sector & $16.50 \pm 13.70$ & $17.23 \pm 14.81$ & -.128 & .900 \\
\hline SR F lumbar sector & $43.08 \pm 8.50$ & $42.92 \pm 9.36$ & 0.045 & .965 \\
\hline SR E sacral sector & $-27.50 \pm 8.36$ & $-26.84 \pm 12.35$ & -.154 & .879 \\
\hline SR E thoracic sector & $-9.25 \pm 15.63$ & $-6.53 \pm 16.06$ & -.427 & .673 \\
\hline SR E lumbar sector & $-10.66 \pm 8.13$ & $-14.07 \pm 8.63$ & 1.014 & .321 \\
\hline FR U sacral sector & $2.42 \pm 4.25$ & $2.36 \pm 8.59$ & .498 & .483 \\
\hline FR U thoracic sector & $23.48 \pm 10.87$ & $35.74 \pm 13.86$ & .348 & .832 \\
\hline FR U lumbar sector & $2.17 \pm 3.54$ & $1.96 \pm 6.35$ & .276 & .493 \\
\hline FR LL sacral sector & $46.00 \pm 12.63$ & $53.21 \pm 9.32$ & 1.653 & .078 \\
\hline FR LL thoracic sector & $9.56 \pm 11.94$ & $11.84 \pm 12.58$ & .082 & .864 \\
\hline FR LL lumbar sector & $39.71 \pm 9.50$ & $39.57 \pm 8.64$ & 0.134 & .798 \\
\hline FR LP sacral sector & $-13.50 \pm 6.32$ & $-19.57 \pm 19.48$ & -.183 & .628 \\
\hline FR LP thoracic sector & $-7.85 \pm 14.56$ & $-4.36 \pm 9.47$ & -.539 & .716 \\
\hline FR LP lumbar sector & $-9.33 \pm 8.94$ & $-11.97 \pm 5.62$ & .019 & .284 \\
\hline
\end{tabular}

Legend: SR - sagittal plane, FR - frontal plane, U - baseline, F - flexion,

$\mathrm{E}$ - extension, LL - lateroflexion left, PL - lateroflexion right (Source: author)

\section{Dimension of shortened muscles}

In the diagnosis of shortened muscles, we consider the level of shortening in four qualitative degrees. I. degree is characterized by sufficient muscle elasticity, II. degree is characterized by moderate level of shortening, III. degree is characterized by medium level of shortening and IV. degree is characterized by significant muscle shortening. At the beginning of the experiment, the students were in II. and III. qualitative degrees (Figure 3). In the experimental group, $60 \%$ of men were in III. degree and $70 \%$ of women in II. degree of shortened muscle dimension (SS). In input measurement total percentage of the experimental 
group was $55 \%$ in II. degree and $45 \%$ in III. degree. The level of muscle imbalance of our experimental group was in a better condition compared to the students of the UKF in Nitra, who were mostly in III. (66.7 \%) and IV. (33.3\%) qualitative degrees (Šimončičová \& Kanásová 2014).

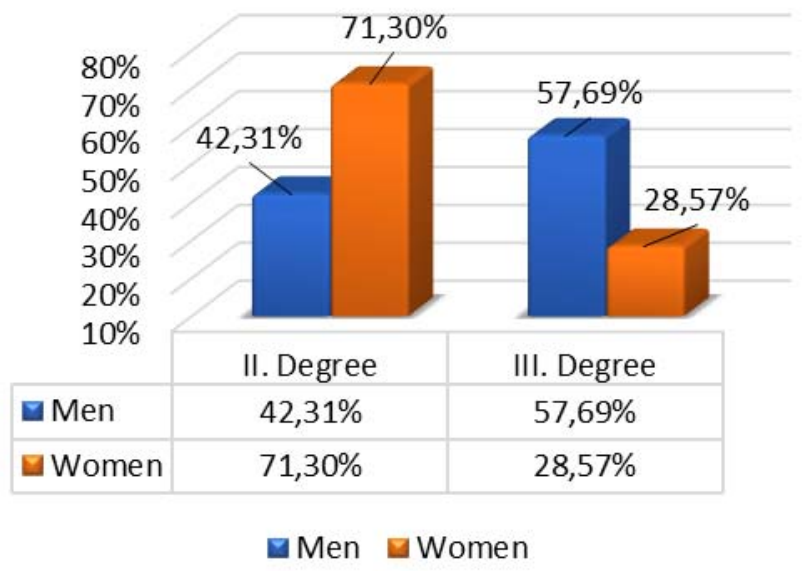

Figure 3

Percentage of students in shortened muscles dimension in initial measurement (Source: author)

Shortening of muscles occurred mainly in men than women in both measurements. In the initial measurement the main shortened muscles in men were $m$. tensor fasciae latae (80 $\%)$, m. triceps surae (80 \%), m. quadratus lumborum (70\%), m. pectoralis major and $m$. rectus femoris $(60 \%)$. On the contrary, the main shortened muscles in women were $m$. tensor fasciae and $m$. erector spinae (60\%) (Figure 4$)$.

m. levator scapulae

m. pectoralis major

m. iliopsoas

m. rectus femoris

$\mathrm{m}$. tensor fasciae latae

$\mathrm{m}$. adductor

m.articularis genus

m. quadratus lumborum

$\mathrm{m}$. erector spinae

m. triceps surae
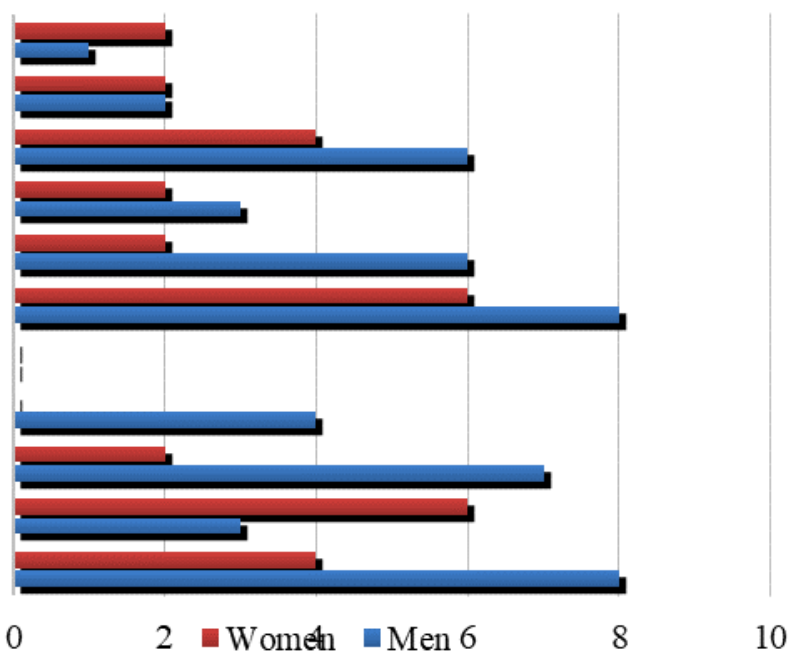

Figure 4

Number of students in shortened muscles dimension of the experimental group in initial measurement (Source: author) 
In repeated measurement, the main shortened muscles in men were $m$. rectus femoris and $m$. tensor fasciae latae (80 \%). Other shortened muscles were $m$. levator scapolae and $m$. pectoralis major (60\%). In women the highest frequency of muscular shortening was found in $m$. rectus femoris and $m$. tensor fasciae latae $(60 \%)$.

Similar results have been observed in the research of Lopata \& Brod'áni (2014). The most frequently shortened muscles in men were m. iliopsoas, m. rectus femoris, m. trapezius (64 $\%$ ) and $\mathrm{mm}$. pectorales $(60 \%)$. The results of our research do not correspond to the results of previously reported by Bendíková et al. (2015). They reported that the most frequently shortened muscles in women were m. rectus femoris (78.32 \%), m. quadratus lumborum (69 $\%)$ and $\mathrm{m}$. pectoralis major (64.5\%).

Table 6

Changes in qualitative degrees of shortened muscles after intervention

\begin{tabular}{|c|c|c|c|c|}
\hline \multirow{2}{*}{$\begin{array}{c}\text { Shortened } \\
\text { muscles }\end{array}$} & \multicolumn{2}{|c|}{ II. } & \multicolumn{2}{|c|}{ III. } \\
\cline { 2 - 5 } Men & test & retest & test & retest \\
\cline { 2 - 5 } & $40 \%$ & 7 & 6 & 3 \\
\hline \multirow{2}{*}{ p } & \multicolumn{5}{|c|}{$\mathbf{0 . 0 2 8 4 0 3 \%}$} \\
\hline \multirow{2}{*}{ Women } & 7 & 9 & 3 & 1 \\
\cline { 2 - 5 } & $70 \%$ & $90 \%$ & $30 \%$ & $10 \%$ \\
\hline \multirow{2}{*}{ p } & \multicolumn{5}{|c|}{$\mathbf{0 . 0 5 9 3 3 7}$} \\
\hline \multirow{2}{*}{ Together } & 11 & 16 & 9 & 4 \\
\cline { 2 - 5 } Chi-Square & $55 \%$ & $80 \%$ & $45 \%$ & $20 \%$ \\
\hline \multirow{5}{*}{ p } & \multicolumn{5}{|c|}{$\mathbf{2 . 8 5}$} \\
\hline
\end{tabular}

(Source: author)

After application of the interventional program, we confirmed by Wilcoxon pair test a statistically significant reduction in the incidence of shortened muscles in experimental group of men by comparing the total score obtained for the shortened muscles dimension between input and output measurements $(\mathrm{p}=0.028403)$. In the experimental group of women, there was no statistically significant difference $(p=0.059337)$. Despite the improvement in the shortened muscles level of the experimental group, the statistically significant difference was not confirmed $(\mathrm{p}=0.091431)$. The total chi-square value was 2.85 , which is less than 3.84 , which is a value $\chi^{2}$ at first degree of freedom (df). (Table 4).

According to Mann-Whitney U Test, we confirmed a statistically significant difference $(p<.05)$ in the total number of points acquired in the shortened muscle dimension comparing 
intersexual difference. We did not confirm statistically significant difference in qualitative degrees of shortened muscle dimension between measurements (Table 7).

Table 7

Shortened muscle scores between men and women of experimental group: Mann-Whitney U Test

\begin{tabular}{|c|c|c|c|c|}
\hline \multirow{2}{*}{} & \multicolumn{2}{|c|}{ Input measurement } & \multicolumn{2}{c|}{ Output measurement } \\
\cline { 2 - 5 } & Points & $\begin{array}{c}\text { Qualitative } \\
\text { degrees }\end{array}$ & Points & $\begin{array}{c}\text { Qualitative } \\
\text { degrees }\end{array}$ \\
\hline $\mathbf{U}$ & 23 & 4 & 17.5 & 4 \\
\hline $\mathbf{Z}$ & 2.003212 & 0.5 & 2.418973 & 0.5 \\
\hline $\mathbf{p}$ & 0.045155 & 0.617075 & 0.015565 & 0.617075 \\
\hline
\end{tabular}

(Source: author)

A statistically significant difference between experimental and control groups was confirmed in the initial measurement based on the number of points achieved in the shortened muscle dimension $(\mathrm{p}=0.000006)$. The final measurement did not confirm a statistically significant difference between experimental and control groups. In both measurements there was a statistically significant difference in the number of points achieved by men of experimental and control groups (Tab 6). On the contrary, women in both groups did not show a statistically significant improvement in the level of shortened muscles.

Table 8

Comparison of gained points of the shortened muscle dimension in experimental and control groups: MannWhitney UTest

\begin{tabular}{|c|c|c|c|c|c|c|}
\hline \multirow{2}{*}{} & \multicolumn{3}{|c|}{ Input measurement } & \multicolumn{3}{c|}{ Output measurement } \\
\cline { 2 - 7 } & Together & Men & Women & Together & Men & Women \\
\hline $\mathbf{U}$ & 32.5 & 74 & 141 & 130.5 & 85.5 & 177.5 \\
\hline $\mathbf{Z}$ & 4.517365 & 3.394786 & 1.58243 & -1.86646 & 3.08371 & 0.595102 \\
\hline $\mathbf{p}$ & $\mathbf{0 . 0 0 0 0 0 6}$ & $\mathbf{0 . 0 0 0 6 8 7}$ & 0.113552 & 0.061978 & $\mathbf{0 . 0 0 2 0 4 5}$ & 0.551776 \\
\hline
\end{tabular}

\section{Discussion}

Spine mobility and function of postural muscles are important for movements of body segments. The sports activities contribute to the level of flexibility and functionality of university students, often active athletes. Asymmetric stress, especially during periods of intense growth, can lead to pathological curvature of the spine (López-Minarro et al. 2010; Lichota \& Plandowska, 2011). Early sports specialization can cause musculoskeletal injuries, reduce flexibility, cause muscle hypertrophy and muscle imbalance (Grabara 2015). 
The results of our research using the SpinalMouse ${ }^{\circledR}$ diagnostic method show that there are variations in the spinal shape in the thoracic sector in women at baseline in the sagittal plane. A half of women had a hyperkyphotic curvature of the thoracic spine. Several studies point to the occurrence of changes in spine curvature in this sector. Physical education students are often active athletes in whom incorrect movement stereotypes are observed as a result of intensive training (Mikul'áková, Urbanová \& Lenková 2017). Lichota \& Plandowska (2011) recorded increased thoracic kyphosis in volleyball players, handball, athletes sprinters and taekwondo wrestlers. Several studies justify the increase in thoracic kyphosis in relation to specific training positions, e.g. a markedly reduced thoracic kyphosis was observed in basketball players compared to their non-training peers.

Lopez-Minarro et al. (2010) evaluated spinal curvature in the sagittal plane and pelvic slope in young kayakers. Spinal defects in the thoracic region affect changes in the position of the lumbar spine and pelvic slope (Wilke et al. 2001). In the stem sector, $35.7 \%$ of women had insufficient curvature, but $21.4 \%$ had excessive curvature of the spine, $71.4 \%$ of women in the cross sector had a good curvature. The greatest problems found in the male population of the study group were mainly in the thoracic spine in the baseline position in the sagittal plane.

Measurements showed that up to $50 \%$ had a flat back, $17 \%$ had a hyperkyphotic position of the thoracic spine. In the spine sector of the spine, $50 \%$ of men had hyperlordotic curvature. We did not see a reduced curve in this sector. $67 \%$ of men had pelvic position in retroflection. Within the frontal plane in the standing position, lateroflexia on the right and left we found in the group of men the occurrence of scoliotic curvature of the spine in all sectors of the spine. The largest deviation was observed in lateral reflex in the left part of the cross-section in up to $54.5 \%$ of men.

We believe that the probands bow in isolation, with lateroflexia occurring only in one spine sector, without the cooperation of other sectors, which may cause wear of individual spine movement segments in the future. In the thoracic and sacral sector of the spine, all probands have the correct curvature of the spine. By evaluating with SpinalMouse ${ }^{\circledR}$, we obtained information about changes in the axial organ in each spine sector. There were no statistically significant differences in the monitored parameters between individual measurements after the intervention. The results of our research correspond to the results of previously reported by Bendíková (2009), which pointed out the affection of students of UMB in Banská Bystrica with structural disorders of the spine, especially scoliosis and occurrence 
of osteophytes. Hrčka, Kovářová \& Beňačka (2011) report the most common back pain in the area of the spine (33\%), cervical spine (29\%) and thoracic spine (17\%) among students of UCM physiotherapy in Trnava.

Therefore, is necessary to pay attention to the state of the musculoskeletal system of students of physical education and sports teachers, to develop appropriate measures to ensure the correction and compensation of structural and functional disorders. After finishing their studies, they should also be able to work independently as specialists in the field of sport for all, nutrition and health for a wide range of the general population, athletes and disabled individuals. They should have acquired practical skills and be able to classify them and apply their training methodology in practice. Their physical abilities and skills should be developed to the required level so that they can present them in the gym. Managers of presumed health, compensatory movement exercises and activities are a prerequisite for the success of their educational activities.

\section{Conclusion}

The results of the research point to the occurrence of negative qualitative changes in the postural system of students of the Faculty of Sports. Other regular activities that do not cause a unilateral burden on the postural system are also an important factor in shaping the correct figure. In a natural experiment following the application of an interventional movement program we aimed at reducing muscle tension, stimulating and improving the flexibility of the fascias, increasing the mobility of individual spine sectors using unconventional equipment. Based on the aim of the current study, we found that:

We recorded no significant changes $(\mathrm{p}>.05)$ in spine mobility as well as in individual sectors of spine by applying the intervention in experimental group. We assume that a longer interval of targeted action of the experimental indicator is needed to achieve positive changes in the area of the spine curvature. In experimental group we noticed changes in the area of the overall muscular system. $30 \%$ of men and $20 \%$ of women improved from III. to II. qualitative degree of shortened muscles. Despite the improvement in the shortened muscles level of the whole experimental group, the statistically significant difference $(p<.05)$ was confirmed only in group of men. In the relatively short time, the positive impact of intervention was recorded in experimental group of students. In regards to good spinal health 
and muscle balance, we assume that targeted movement program can have preventive effect against functional and structural disorders.

This study was supported by the scientific Grant Agency of the Ministry of Education, Science, Research and Sport of the Slovak Republic and the Slovak Academy of Sciences under the Grant No. 1/0376/19 "Risk factors of health of university students in physical activity".

\section{References}

1. AEBI, M., 2005. The Adult Scoliosis. In: European Spine Journal [online]. 14(10), pp 925-948. Accessible from: https://doi.org/10.1007/s00586-005-1053-9.

2. AMERICAN HEART ASSOCIATION, 2015. Recommendations for exercise for physically active adults. [cit. 2015-04-25]. Accessible from: https://www.heart.org/HEARTORG/ GettingHealthy/PhysicalActivity/FitnessBasics American-Heart-Association-Recommendations-for-Physical-Activity-in-Adults_UCM_ 307976_Article.jsp

3. BURSOVÁ, M., 2005. Kompenzační cvičení - uvolňovací, protahovací, posilovací. Praha: Grada Publishing. ISBN 80-247-0948-1

4. BENDÍKOVÁ, E., 2009. Význam využívania športovo-rekreačných aktivít v spôsobe života vysokoškolákov. In: Šport a zdravie v hodnotovej orientácii vysokoškolákov: zbornik z vedeckej konferencie. Bratislava: Univerzita Komenského, pp. 87-92. ISBN 97880-223-2706-0.

5. BENDÍKOVÁ, E. et al., 2015. The influence of exercise program on the muscular system of female pupils in the lessons of physical education and sport. In: Sport science [online]. 8(2), pp. 70-75 [cit. 2018-04-21]. ISSN: 1840-3670. Accessible from: https://www.sposci.com/PDFS/BR0802/SVEE/04 \%20CL \%2013 \%20EB.pdf

6. BENDÍKOVÁ, E. 2016. Obsahová náplň vyučovacej cvičebnej jednotky so zdravotnými cvičeniami. In: Športový edukátor [online]. 9(2), pp. 34-39 [cit. 2018-03-22]. Accessible from: http://www.ktvs.pf.ukf.sk/images/ \%C5 \%A1portov \%C3 \%BD \% 20eduk \%C3 $\%$ A1 tor/Sportovy_edukator_2_2016\%20(1).pdf\#page $=35$

7. BERÁNKOVÁ, L., R. GRMELA, J. KOPŘIVOVÁ \& M. SEBERA, 2012. Zdravotní tělesná výchova. Brno: Masarykova univerzita [online]. ISSN 1802-128X.

8. CHEN, H., C. YARNAL, J. D. HUSTAD \& SIMS, 2016. Take a Selfie of Life: A Qualitative Exploration of College Students' Self-Reflections on Free Time Use and 
Personal Values. In: Journal of College and Character [online]. 17(2), pp. 101-115 [cit. 2018-04-08]. ISSN 2194-587X. Accessible from:

https://www.tandfonline.com/doi/full/10.1080/2194587X. 2016.1159226

9. ČERMÁK, J., O. CHVÁlOVÁ, V. BOTLÍKOVÁ \& H. DVOŘÁKOVÁ, 2008. Záda už mě nebolí. Praha: Jan Vašut s.r.o. ISBN 80-7236-117-1.

10. DOHI, E. SpinalMouse ${ }^{\circledR}$ [online]. [cit. 2013-02-08] Accessible from: http://spinalmouse.ro /en/contact/.

11. DOSTÁlOVÁ, I. \& M. SIGMUND, 2017. Pohybový systém. Anatomie, diagnostika, cvičení, masáže. Olomouc: Poznání. 313p. ISBN 978-80-87419-61-8.

12. DYLEVSKÝ, I., 2009. Speciální kineziologie. Praha: Grada Publishing. ISBN 978-80247-1648-0.

13. GRABARA M. 2015. Comparison of posture among adolescent male volleyball players and non-athletes. In: Biology of Sport. 32(1), pp. 79-85.

14. GÓRNICKA, J., 2014. Cesta ke zdravé páteři a kloubům. Zlín: Jan Vašut s.r.o. ISBN 978-80-7236-830-3.

15. HRČKA, J., M. KOVÁŘOVÁ \& J. BEŇAČKA, 2011. Pohybová aktivita edukantov fyzioterapie vo vol’nom čase a jej reflexia na vybraných zdatnostných azdravotných charakteristikách. Trnava: Univerzita sv. Cyrila a Metoda v Trnave. ISBN 978-80-8150$323-8$.

16. JANDA, V., 1982. Základy kliniky funkčních (neparetických) hybných porúch. Brno.

17. KANÁSOVÁ, J., 2017. Svalová nerovnováha detí stredného a staršieho školského veku. In: Športový edukátor [online]. 10(1), p. 57 [cit. 2018-04-21]. ISSN: 1337-7809. Accessible from: http://www.ktvs.pf.ukf.sk/images/ \%C5 \%A1portov \%C3 \%BD \%20 eduk \%C3 \% Ator/sportovy_edukator_1_2017.pdf

18. KOCIOVÁ, K. \& W. MIKULÁKOVÁ, 2011. Kineziologická analýza axiálneho systému človeka pomocou zariadenia Spinal Mouse. In: Molisa 8. Prešov, Grafotlač, s.r.o, Prešov. pp. 59-66.

19. KOLÁ̌̆, P. et al., 2009. Rehabilitace v klinické praxi. Praha: Galén. ISBN 978-80-7262$657-1$.

20. KOPŘIVOVÁ, J. \& L. BERÁNKOVÁ, 2002. Problematika funkčních poruch pohybového aparátu. In: Medicina Sportiva Bohemica Slovaka. Praha: ČSTL. 11(3), pp. 210. ISSN 1210-5481. 
21. LENKOVÁ, R. \& I. BORŽÍKOVÁ, 2018. Zdravotná telesná výchova. Prešov: Fakulta športu PU v Prešove. Grafotlač Prešov. ISBN 978-80-555-2166-4.

22. LENKOVÁ, R., W. MIKULÁKOVÁ, E. LABUNOVÁ \& K. URBANOVÁ, 2018. Diagnostika funkčných porúch pohybového systému pre študijné programy telesná výchova, šport pre zdravie a fyzioterapia. Prešov: Fakulta športu. 139p. ISBN 978-80555-2070-4.

23. LEVITOVÁ, A. \& B. HOŠKOVÁ, 2015. Zdravotně-kompenzační cvičení. Praha: GRADA Publishing. ISBN 978-80-247-8436-8.

24. LICHOTA, M., M. PLANDOWSKA \& P. MIL, 2011. The shape of anterior - posterior curvatures of the spine in athletes practising selected sports, In: Polish Journal of Sport and Tourism. 18(2), pp. 112-116.

25. LÓPEZ-MINARRO, P.A., J.M. MUYOR \& F. ALACID, 2010. Sagittal spinal curvatures and pelvic tilt in elite young kayakers, In: Medicina dello sport. 63(4), pp. 509-519.

26. MIKULÁKOVÁ, W., K. URBANOVÁ \& R. LENKOVÁ, 2017. Quality of the postural system of university students In: Scientific review of physical culture [online]. 7(4), pp. 93-98. ISSN 2083-8581.

27. MIKULÁKOVÁ, W., K. URBANOVÁ, R. LENKOVÁ \& I. BORŽÍKOVÁ, 2017. Monitoring of disturbed posture in basketball and volleyball players. In: Potrzeby $i$ standardy wspólczesnej rehabilitacji: IX miedzynarodowe dni rehabilitacji: streszczenia. Rzeszów, Bonus Liber. ISBN 978-83-65441-65-2.

28. NORRIS, CH. M., 1995. Spinal stabilisation. Muscle imbalance and the low back. In: Physiotherapy No. 3.pp. $127-138$.

29. RIPANI, M., A. CESARE, A. GIOMBINI, L. AGNELLO \& F. FAGNANI, 2004. Spinal curvature: comparison of frontal measurements with the Spinal Mouse and radiographic assessment In: Journal of Sports Medicine and Physical Fitness. 48(4), pp. 488-94.

30. ŠIMONČIČOVÁ, L \& J. KANÁSOVÁ, 2014. Vplyv prostriedkov kondičnej gymnastiky na odstraňovanie svalovej nerovnováhy u študentov 2. ročníka SAR UKF v Nitre. In: Šport a rekreácia 2014: zborník vedeckých prác [online]. Nitra: KTVŠ PF UKF, pp. 2026 [cit. 2018-03-24]. Accessible from: http://www.ktvs.pf.ukf.sk/images/ \%C5 \%A0port \%20a \% 20rekre \%C3 \%A1cia/Zbornik \%20Sport \%20a \%20rekreacia \%202014.pdf

31. THURZOVÁ, E., 1992. Svalová nerovnováha. In: LABUDOVÁ, J., THURZOVÁ, E. 1992. Teória a didaktika telesnej výchovy oslabených (vybrané kapitoly). Bratislava: FTVŠ UK, pp. 7 - 46. 
32. VÉLE, F., 2006. Kineziologie: Přehled klinické kineziologie a patokineziologie pro diagnostiku a terapii poruch pohybové soustavy. Praha: Triton. ISBN 80-7254-837-9.

33. WILKE, H., P. NEEF, B. HINZ, H. SEIDL \& L. CLAES, 2001. Intradiscal pressure together with anthropometric data-a data set for the validation of models, In: Clinical biomechanics. 16(1), pp. 111-126. 